\title{
The Modification of LMS Quipperschool to Improve Senior High School Students' Concept Mastery of Biology Subject, Topic: Human Reproduction Health
}

\author{
Muhammad Luthfi Hidayat \\ Program Studi Pendidikan Biologi, Universitas Muhammadiyah Surakata \\ Email: m.luthfi@ums.ac.id
}

(Received: February-2018; Reviewed: February-2018; Accepted: March-2018; Published: April-2018) access under license CC BY-NC-4.0 (https://creativecommons.org/licenses/by-nc/4.0/).

\begin{abstract}
This research aims to: (1) develop a biology Learning Management System (LMS) in Human Reproduction System Health with Quipper School platform, (2) develop an instrument of biology to improve student's concept mastery at SMA Muhammadiyah I Klaten. This developmental research referred to the design and development research (DDR) model suggested by Richey \& Klein (2007) grouped into six developmental procedures, and simplified into five procedures including (a) identifying the problem, $(b)$ describing the objectives, $(c)$ designing and developing product, $(d)$ testing and evaluating product, $(e)$ communicating the testing results. The data were analyzed using the parametric statistical model of ANCOVA test with the significance level of 0.05. The research finding reveals that the implementation of the LMS is in the "very good" category. There is a significant difference in the concept mastery $(p=0.013)$ between the experimental and control class after the use of Human Health Reproduction LMS with $p<0.05$. The conclusion of this research is that the use of LMS of Human Health Reproduction is able to improve the concept mastery of students
\end{abstract}

Keywords: LMS; concept mastery; quipper school; human health-reproduction.

\section{INTRODUCTION}

In the 21 st century, the use of information and computer technology (ICT) in learning becomes a necessity. ICT-based Biology Learning provides a number of benefits such as providing access to learning resources, overcoming the difficulties in bringing learning resources into the classroom, and reducing the bulkhead that is common in conventional learning. For example, in Biology, topics about the human reproductive system that addresses issues surrounding the world of adolescent sexuality and health reproduction are still considered taboo to be discussed openly in the classroom. In fact, this material is quite interesting to be discussed in high school / MA as students are in the phase to enter puberty in which they have a high curiosity.

If their curiosity is not treated properly, like they are not properly informed by their parents or school teachers, it could bring a detrimental effect on them. For teenagers, it is important to create a comfortable and safe condition when discussing their reproductive health or sexuality issues. However, in general learning in schools, the students' right to obtain the further information about their health reproduction is confounded in the eastern culture which still considers the discussion of sexuality to be taboo. In addition, some teachers still lack the privacy space for students who want to ask further questions due to the general class atmosphere. 
The difficulties to find the safe and comfortable discussion room can actually be solved by ICT-based Biology learning in schools, by integrating health reproduction education in classroom learning, in accordance with the curriculum used in schools using information technology (ICT). The technology in this study is expected to bridge the students' curiosity towards the biology material about health reproduction in a more private space.

This goal is then supported by the development of e-learning as an alternative learning system to make the learning method becoming more interactive, broader, and conducted not only in the classroom (Surjono, 2011). E-Learning can overcome the teachers and students' problem related to the limitation of available time, thereby providing a great opportunity for making collaboration and accessing content which is relevant to the student's style and learning needs. By fulfilling this need, the students' mastery of concepts they learn in Biology can be achieved.

Teaching Biology in Senior High School by utilizing ICT which aims to align it with dynamic learning spirit and students' need, requires a web-based learning management system or often called Learning Management System (LMS). LMS is defined by Piña (2013) as a software program that is based on a server or cloud computing with an interface containing the form of database information about the user, course content (learning), and the activity course, thus it can accommodate the need of richer interaction between students and teachers.

Ghareeb \& Riad (2008) and Gautreau (2011) explained the standard features that should be available to categorize a web-based learning software as a Learning Management System (LMS). Some of them are discussion room, learning material files, report cards, announcements, ratings, and multimedia elements. The LMS should also provide access to student-centred learning approaches, provide a high accessibility through multi-screen, learning assessment and evaluation features, and subject content which is well administratively managed.

Laurillard (2002), Chaubey (2015), and Forouzseh, (2012) explained that an LMS as hypermedia should also have management features like a class, which has: 1). educational goals related to the learning content. 2). Lesson plans which are standardized on subjects. 3).
Lessons which have several levels of adaptive and consistent classes. 4). portfolio management system 5). learning level that is presented based on the each student's level, 6) ability to make a combination with human resource system 7). content that can incorporate third-party providers of learning device. 8). gap evaluation mechanisms between student competencies, and managing skills and skill points 9). compilation of supportive evaluations, 10). security facilities such as passwords and codes.

The Learning Management System (LMS) platform which was chosen for this research was Quipper School. It is a start-up learning that has three main features that can be utilized in the practice of e-learning in schools such as Quipper School Link, Quipper School Learn and Quipper School Create.

Quipper School Learn is a portal special for students where they can access or read the subject matter, answer questions, send messages to teachers, and see the performance of their classmates. Quipper School Link is a portal for teachers, where teachers can create online classes, submit assignments, view student progress, organize formative and summative tests, and send messages to students. The Quipper School Create is a portal where teachers can create their own educational materials to use at Quipper School (Hidayat, 2014).

One of the advantages of Quipper School Learn is that there is available learning content adapted to KTSP and K13 curriculum for all subjects from junior to senior high (IPA or IPS). However, the content cannot be changed because it has presented a package with the system. If the teacher wants to take the initiative to create his own content according to students' needs or any learning that they want, the teacher can access Quipper create. Through this portal, LMS Quipper school can be modified according to the purpose of this research, it is focusing on the reproductive health, which is the part of the topic of Human Reproduction System in class XI IPA.

\section{METHOD}

This research development employed Design and Development Research or DDR design by Jones (2000) and Richey \& Klein (2007).

Product testing was conducted through several stages as follows. 1) conducting a one- 
on-one test with five learners to the product that would be developed. Information/data was collected through observation, interview, questionnaire, and continued data analysis, 2). Revising the product based on feedback and suggestions from the one-to-one test. Revisions are changes or improvements made to products based on input from expert media validators and material validators, 3). Conducting small group trial to 15 students of IPA XII class who had learned the material and had the ability to operate the software on windows and Android operation system. This small group trial aimed to get a response from learners about the feasibility of content, images, concepts and appearance of products that have been developed. In addition, this stage aims to perform empirical tests on the construct validity and the content validity of the instrument items to measure the concept and the application mastery of 15 high school teenagers who have ever received material about reproduction system.

An objective test was used to assess the conceptual and the application mastery. That means there were only two types of possible answers, which are true or false, or yes-no. Each item that is answered correctly is generally given a score of 1 (one) and each wrong answer is given a score of 0 (zero), 4). After a small group trial is done, the next step is a revision. Revisions were made based on the findings obtained from the learners' responses to the media from content feasibility, language and image, and appearance aspect, 6). Conducting a major field trial on 1 school, with 20 experimental class subjects and 20 control class subjects. The main field test design used Quasiexperiment design with pre-tests and posttest (Donald, 2007).

The quasi-experimental design was chosen because the random assignment assumption of the students in the treatment class was not fulfilled, either because of the school's policy or the condition of the learners. Researchers employed a quasi-experimental design to consider internal and external validity issues and consider this in their interpretation and analysis of data. This quasi-experimental research involved Nonrandomized Subject, PretestPosttest Control-Group Design form (Donald, 2007).
The data in this study was collected through interviews, Student Work Sheets (LKPD), instructional learning sheets, and concept applications mastery tests (pretest and posttest).

The subject of this study is divided into two, namely reviewers and learners who will use the products developed. The selected reviewers are experts in their field with qualifications, ie materials experts, media experts, teachers and peers, as well as a limited number of students for testing.

Limited trial subjects were six teenagers of SMAI IPA1 from schools with similar characteristics which were consisting high, moderate, and low-ability learners (two students for each category). The field trial subjects are the XI IPA class with a total of 40 students (20 control class students and 20 treatment class students) with standard qualifications including being able to operate smartphones, laptops with Windows operating system and internet.

A hypothesis was tested by using analysis of covariance (ANCOVA). The test criterion is: $\mathrm{H} 1$ is accepted if the significance value is less than 0.05 (Latan, 2014). The assumptions that must be fulfilled before performing the analysis by conducting the test of analysis of covariance (ANCOVA) are normality, homogeneity, and regression, as shown in Table 3.1.

\section{RESULTS AND DISCUSSION}

\section{Results}

The observation of the implementation of learning using Biology LMS RH was conducted by one observer. Observer put tick mark $(\sqrt{ })$ on observation instrument sheets which have been provided. Observation of the learning implementation was done within two meetings, namely meeting I and meeting II. The observation on the implementation of learning on field trials was done well that is $100 \%$ in two meetings.

The data obtained from the concept mastery test which was described previously consisted of pretest and posttest containing 25 items of multiple choice questions. Descriptive analysis of data related to mastery of concept and the application stage showed the mean, minimum, and maximum values. The result of descriptive analysis of concept mastery data can be seen in Table 3.2 
Based on the pretest and posttest values, gain score can also be calculated. The gain score calculation refers to the gain score equation (Hake, 1998). The equations for the gain score technique are as follows:

The result of the gain score is then interpreted into the criterion of $(\mathrm{g})((<\mathrm{g}\rangle)\rangle 0.7$ $=$ high, value $0,3<(<\mathrm{g}\rangle)<0.7=$ medium, and $(<\mathrm{g}\rangle)<0.3=$ low $)$.

Based on the data and the calculation, it can be seen that the average value of gain score was 0.563 and was classified into medium

$$
\begin{aligned}
& \text { Gain score }(g) \\
& =\frac{\text { posttest score }- \text { pretest score }}{\text { maximun score }- \text { pretest score }}
\end{aligned}
$$

criteria. The data shows that out of 20 students, one person experienced improvement on concept mastery $\mathrm{f}$ with the high criterion, 17 people experienced improvement of concept mastery with the medium criterion and 2 people with the low criterion.

Table 3.1 Data Analysis Descriptive of Assumption Test on Experimental and Control.

Experimental Class

\begin{tabular}{llcl}
\hline Assumption test & Concept Mastery on Experimental class & Note \\
\hline Normality & 0,018 & Not & normal \\
& & distribution & \\
Homogeneity & 0,572 & Homogeny & \\
Regression & 0,015 & Linear Regression \\
\hline
\end{tabular}

Control class

\begin{tabular}{lll}
\hline Assumption test & Concept Mastery on Experimental class & Note \\
\hline Normality & 0,200 & Normal distribution \\
Homogeneity & 0,551 & Homogeny \\
Regression & 0,015 & Linear Regression \\
\hline
\end{tabular}

Table 3.2. Results of Descriptive Analysis Pretest and Posttest og Concept Mastery

\begin{tabular}{lll}
\hline Class & Pretest & Posttest \\
\hline Experimental & 43,05 & 75,10 \\
Control & 51,25 & 70,10 \\
\hline
\end{tabular}

Table 3.3. The Data of Ancova Hypothesis Testing

\begin{tabular}{lll}
\hline Variable & Significant Score & Note. \\
\hline $\begin{array}{l}\text { The concept mastery on the } \\
\text { application }\end{array}$ & 0,04 & $\mathrm{H}_{1}$ is accepted \\
\hline
\end{tabular}

\section{Discussion}

For this research purpose, the modification of LMS Quipperschool was conducted through Quipper create portal. In that portal, modifications were made in the material related to the human reproductive system that was previously still very general to be more in-depth on human reproductive health. Some examples of material development include the ethics of socializing between men and women who have been able to perform sexual reproduction, risky behavior/lifestyle to be avoided by high school students because of its potential to be the cause of the spread of sexually transmitted diseases (PMS), as well as advice from doctors, clergy, and health experts to prevent deviant behavior and the risk of contracting reproductive organ diseases. 
The modification was, besides a change in written concepts in learning, the addition of video graphics counselling and short films about the real story of people living with HIV / AIDS, which aimed to educate high school students especially class XI IPA so they would avoid similar cases.

Modifications were also made on the items of the online learning evaluation. Previously, the problems that were defaulted on the system were ten multiple choices questions without discussion rubric. Once modified, the number of questions given to the students increased to 25 with the type of HOT (High Order Thinking) in the form of multiple choice with paired grains and the problem of causality equipped with a discussion rubric to measure the learner's concept and applications mastery.

Student concepts mastery was calculated using the sensitivity index test (Is) to investigate test items. The results obtained from the sensitivity index (Is) of 25 questions items which were analyzed indicated that there were 22 of good and valid questions and the average score of the experimental class was better or higher than that of the control class (Subali, 2012).

The next step was to identify the better learning model either the one in the experimental class which used LMS Biology Kespro or the learning in control class without LMS media, which was followed by analysis of covariance (ANCOVA) with significance level 0,05 . The data used in this test was the average value of concept mastery as it has discrete data.

ANCOVA test aimed to test the hypothesis to identify the effect of treatment on learners concept mastery. Summary of hypothesis testing results is presented in Table 3.3.

Based on analysis of covariance test (ANCOVA) results shown in Table 4, it was found that the Sig. value of the concept mastery variable was 0.04 . Because the sig value. sig. $<0.05$, H0 was rejected or H1 was accepted. Therefore, it can be said that there was a significant influence of LMS Quipper school usage on the improvement of learners' concept mastery and application stage of Human reproduction system material for class XI.

The analysis of the data assessment and revision indicates that the product is feasible to be used in the next stage after a revision based on the input given. The results of the assessment that has been done by the material expert indicated that the quality of learning was categorized very good and the quality of the content's validity was categorized as good. In terms of the quality of media display, display and language, interaction, and software engineering, they are categorized into very good.

Based on the assessment conducted by the teacher, learning quality aspects and the material content validity were categorized as very good. Also, the quality of media display, display and language, interaction, and software engineering was included into the very good criteria.

The assessment was continued by learners which were divided into small groups and then was assessed in the large group. Assessments from learners in small groups categorized the material into good category and media into good criteria. While the assessment conducted by learners in large groups (field trials) classified the material and media aspects into the good category.

A good quality management and learning strategies based on internet multimedia (LMS online) both support the effectiveness of students' learning to improve learning outcomes and concept mastery. The improvement of learning outcomes can be seen from the gain scores on the ability to master the concept before and after using the LMS which was an average of 0.563 , meaning it increased to average criteria. The pretest result of concept mastery at the meeting I showed the average value of 4,305 while the posttest showed the average value of 7.51. Posttest indicated that $70 \%$ of students reached the Minimum Criteria for Mastery Learning (KKM) (the value $\geq 75$ ).

Hwang (2012) stated that a learning media with animation as an additional learning resource for students can improve students' mastery on a difficult concept, it is the abstract concept that is usually displayed through text and static images. Nikmah (2013) also showed a close correlation between the use of smartphones with the learners' achievements. Switching smartphone use that previously does not support the learning to be an activity that supports the learning can improve learners' learning outcomes and understanding on the concept.

Based on the results of the field trial stage, it can be regarded that Biology LMS Quipper school with Reproductive Health topic has an 
effect to improve the learners' concept mastery, therefore, it is feasible to be used as a biology learning media, especially in human reproductive health sub material. The feasibility of the product is supported by the results of the media assessment which showed that the quality of the material and the media is very good and good. Bialo (1996) and Yi (2013) reinforced that the use of multimedia can improve attitudes toward learning. In addition, the appropriate educational technology provides a significant positive effect on the learners' achievement.

\section{CONCLUSIONS AND SUGGESTIONS}

Based on the results of research development, analysis, and discussion, there are some conclusions that can be withdrawn as follows. Firstly, the LMS of Reproductive Health Biology, Quipper School-based, humans' reproductive health, which is being developed is feasible and can be used to support Biology learning in SMA Muhammadiyah 1 Klaten, both classically and individually, on Android and iOS operating system smartphones, and Windowsbased computer devices with the internet connection. Secondly, the Learning Management System of Quipper school in reproduction health materials can improve the concept mastery of the high school students Muhamamdiyah 1 Klaten class XI IPA. The concept mastery improvement can be seen from the average gain score of 0.563 with the criteria of "medium" and there is an increase in the mastery of learning outcomes to be $70 \%$. Third, the comparison of concept mastery between treatment class and control class showed a significant improvement on the concept mastery in the treatment class LMS Quipperschool compared to the control class.

Based on the results that have been presented, it is suggested as follows. First, the Learning Management System Quipper school, Reproductive Health sub-topic, effectively improves the learner's concepts mastery, so that biology teachers and learners in SMA Muhammadiyah 1 Klaten is expected to use this product as an alternative learning media in school. Secondly, the use of LMS, Quipper school-based, in a learning process requires motivation and guidance from teachers to achieve optimal results. Third, in using the Biology Quipper school, Reproductive Health subtopic, in the learning process, it is recommended to apply Blended Learning as the variety of learning methods in order to reduce the risk of slow connections when it is used together in school. Fourth, the next researcher can use this LMS to other Biology materials. Fifth, the next researcher should use the better and more appropriate analysis of items so that the questions used in the research are good and valid. Lastly, media users who do not have an Android smartphone are suggested to use a laptop or PC media to open this app.

\section{REFERENCES}

Bialo, E. R., \& Jay S. K. (1996). The effectiveness of technology in school: A Summary of recent research. Journal SLMQ. 25 (1), 1-14.

Chaubey,A. \& Bhattacharya, B. (2015). Learning management system in Higher education. IJSTE - International Journal of Science Technology \& Engineering. 2 (3), 49-58

Donald, A., Jacobs, L.C, \& Razavieh, A. (2007). Pengantar penelitian dalam pendidikan, cetakan ke-3 (terjemahan Arief Furchan). Yogyakarta: Pustaka Pelajar

Forouzseh, M., \& Darvish, M. (2012). Characteristics of learning management system (LMS) and its role in education of electronics.. The $8^{\text {th }}$ International Scientific Conferencee Learning and software for Education Bucharest, April 26-27, 201210.5682/2066-026X-12-079

Gautreau, C. (2011). Motivational factors affecting the integration of a learning management system by faculty California State University Fullerton. The Journal of Educators Online, 8(1), 2-11

Ghareeb, A.H. \& Riad, A.M. (2008). A service oriented architecture to integrate mobile assessment in learning management systems. Turkish Online Journal of Distance Education-TOJDE. 9 (2) 30-40.

Hake, R. R. (1998). Interactive engagement versus traditional methods: A six thousand 
student survey of mechanics' test data for introductory physics courses. The American Journal of Physics Research

Hidayat, M.L.(2014) Kajian Manajemen Sistem Belajar Quipper School Indonesia sebagai Online Learning Management System. Academia.edu. diakses http://www.academia.edu.10 februari 2018

Hwang, I., Tam M., Lam S. L., \& Lam P. (2012). Review of Use of Animation as a Supplementary Learning Material of Physiology Content in Four Academic Years. The Electronic Journal of $e$ Learning. 10 (4), 376.

Jones, T.S, \& Richey, R.C. (2000). Rapid prototyping methodology in action: a developmental study. Jornal ETR\&D. 48 (2), pp.63-80

Latan, H. (2014). Aplikasi analisis data statistik untuk ilmu sosial sains dengan ibm spss. Bandung: Alfabeta

Laurillard, D.(2002). Rethinking university teaching: a conversational framework for the effective use of learning technologies, $2^{\text {nd }}$ edition. USA \& Canada: Taylor \& Francis Publisher

Nikmah, A. (2013). Dampak penggunaan handphone terhadap prestasi siswa. Ejurnal Dinas Pendidikan Kota Surabaya. 5(2), 10-19
Peffers, et.al. (2008). A Design science research methodology for information systems research. Journal of Management Information Systems, Volume 24 Issue 3, Winter 2007-8, pp. 45-78.

Piña, A. A. (2013). Learning Management Systems: A Look at the Big Picture. In Y. Kats (Ed.), Learning Management Systems and Instructional Design: Best Practices in Online Education (pp. 1-19). Hershey, PA: . doi:10.4018/978-1-4666-3930-0.ch001

Richey, R.C., \& Klein, J.D. (2007). Design and development research; strategies and issues. Mahwah, $\mathrm{Nj}$ : Lawrence Erlbaum associates, publisher

Subali, B. (2012). Prinsip asesmen dan evaluasi pembelajaran. Yogyakarta: UNY Press

Surjono, Herman D. (2011). Membangun course e-learning berbasis moodle. Yogyakarta: UNY Press

. Yi, S. Y., Yu Y. L., Lin H., \& Wen H. (2013). The evaluation of use the mobile phone learning english in taiwan. International Journal of information and education technology. 3 (2), 189-191 